DIMENSI, VOL. 8 , NO. $3: 449-472$

NOVEMBER 2019

ISSN: 2085-9996

\title{
IMPLEMENTASI PROGRAM PENGANGKUTAN SAMPAH DI KECAMATAN BELAKANG PADANG
}

\section{IMPLEMENTATION OF WASTE TRASNPORT PROGRAMS IN BELAKANG PADANG DISTRICT}

\author{
Dendi Sutarto ${ }^{1}$, Muhammad Solihin ${ }^{2}$ \\ ${ }^{1}$ (Prodi Ilmu Pemerintahan, Fisipol, Universitas Riau Kepulauan, Indonesia) \\ ${ }^{2}$ (Prodi Ilmu Pemerintahan, Fisipol, Universitas Riau Kepulauan, Indonesia) \\ 1dendi_sutarto@yahoo.co.id, ${ }^{2}$ sm10rome@gmail.com
}

\begin{abstract}
Abstrak
Pengangkutan sampah di Kota Batam yang dilaksanakan oleh Dinas Lingkungan Hidup Kota Batam yakni hanya di 9 kecamatan. 9 kecamatan tersebut umumnya tersebar di mainland area, sedangkan terdapat 3 Kecamatan yang tidak dapat di jangkau oleh Dinas Lingkungan Hidup Kota Batam dikarena keterbatasan anggaran dan fasilitas. 3 Kecamatan tersebut adalah Galang, Bulang, dan Belakang Padang yang sebagian besar daerahnya berupa pulau-pulau kecil. Pada Kecamatan Belakang Padang saat pertama kali datang berkunjung akan melihat sampah memenuhi bibir pelantar di pelabuhan hingga ke sekitar pasar rakyat dan lapangan. Hal ini sangat krusial karena jika sampah tersebut masuk laut akan sangat susah untuk terurai. Tujuan penelitian ini untuk mengetahui Implementasi Program Pengangkutan Sampah di Kecamatan Belakang Padang. Tempat penelitian di Kecamatan Belakang Padang.Jenis penelitian ini mengunakan pendekatan kualitatif dengan analisa deskriptif. Hasil penelitian ini pengangkutan sampah di kecamatan Belakang Padang sudah baik, namun pengangkutan sampah di laut masih belum dilakukan. Frekuensi pengangkutan sampah sudah sesuai. Cakupan pengangkutan sampah masih melayani 2 kelurahan, sedangkan 4 kelurahan belum terlayani. Masyarakat merasa program ini sudah tepat guna.
\end{abstract}

Kata Kunci ; Pengangkutan Sampah, Implementasi Kebijakan, Kebijakan Publik

\begin{abstract}
The garbage transportation in Batam City carried out by the Batam City Environment Agency is only in 9 subdistricts.9 These subdistricts are generally scattered in the mainland area, while there are 3 Districts that cannot be reached by the Batam City Environment Service due to budget and facilities limitations. 3 The subdistricts are Galang, Bulang, and Balik Padang which are mostly small islands. In the Padang Padang Subdistrict, when they first visited, they saw that the garbage filled the shipping lip at the harbor to the surrounding people's markets and fields. This is very crucial because if the garbage enters the sea it will be very difficult to decompose. The purpose of this study was to determine the Implementation of the Trash Transport Program in the District of Padang Padang. Place of research in the district of Padang Padang. This type of research uses a qualitative approach with descriptive analysis. The results of this study transport garbage in the district of Padang Padang is good, but transportation of waste in the sea is still not done. The frequency of transporting garbage is appropriate. Coverage of transporting waste still serves 2 villages, while 4 villages have not been served. The community feels this program is appropriate.
\end{abstract}

Keywords : Waste Transportation, Policy Implementation, Public Policy 


\section{PENDAHULUAN}

\section{Latar Belakang Masalah}

Saat ini timbunan sampah di Indonesia per tahun masih tidak diolah dengan baik, menurut data dari Kementrian Lingkungan Hidup dan Kehutanan pada 2015 tentang pengelolaan sampah di Indonesia 66,39 persen sampah ditimbun dan sampah tidak diolah sebanyak 19,62 persen. Total ada sekitar 86.01 persen sampah belum terolah sama sekali di Indonesia. Hal ini tentu cukup mempritahatinkan apalagi mengingat pada Tahun 2025 Pemerintah telah menetapkan target dalam pengurangan sampah kantong plastik sebesar 30 persen sesuai dengan Perpres Nomor 97 Tahun 2017 tentang Kebijakan dan Strategi Nasional Pengelolaan Sampah Rumah Tangga dan Sampah Sejenis Rumah Tangga.

Provinsi Kepulauan Riau merupakan wilayah kepulauan dengan terdiri dari lebih 300 pulau. Salah satu pusat ekonomi di Provinsi ini adalah kota Batam yang terdiri dari Batam, Rempang dan Galang. Saat ini jumlah penduduk kota Batam per 2015 berjumlah 1.020.529 jiwa. Diperkirakan penduduk akan tumbuh sekitar 2,8 Juta jiwa pada tahun 2037. Dengan estimasi peningkatan penduduk tersebut kota Batam tentu tak luput dari masalah-masalah sosial seperti kota-kota besar lainnya di Indonesia. Salah satu masalah yang dihadapi adalah permasalahn sampah.

Di Kota Batam terdapat 12 kecamatan yang tersebar menjadi bagian mainland dan hinterland. Pada Penelitian Solihin dan Ronald (2018) ${ }^{1}$ Pengangkutan sampah di Kota Batam yang dilaksanakan oleh Dinas Lingkungan Hidup Kota Batam yakni hanya di 9 kecamatan. 9 kecamatan tersebut umumnya tersebar di mainland area, sedangkan terdapat 3 Kecamatan yang tidak dapat di jangkau oleh Dinas Lingkungan Hidup Kota Batam dikarena keterbatasan anggaran dan fasilitas. 3 Kecamatan tersebut adalah Galang, Bulang, dan Belakang Padang yang sebagian besar daerahnya berupa pulau-pulau kecil. Dalam ilmu pelayanan publik dengan semangat otonomi daerah tentu akan terasa janggal jika ada suatu tempat yang tidak menerima pelayanan. Pada penelitian ini penulis akan

\footnotetext{
${ }^{1}$ Solihin, Muhammad dan Parlindungan, Ronald. 2018. Implementasi Program Pengangkutan Sampah di Kota Batam Tahun 2017: Volume 2 No 2. Hal 88-89
} 
memusatkan perhatian pada Kecamatan Belakang Padang dikarenakan jumlah penduduk Belakang Padang lebih banyak dari pada penduduk Kecamatan Galang dan Bulang seperti yang tertera pada Tabel 1 dibawah ini.

Tabel 1 Jumlah Penduduk Kecamatan Belakang Padang, Bulang dan Galang Tahun 2016

\begin{tabular}{|l|l|r|r|r|}
\hline No & Kecamatan & Laki-Laki & Perempuan & Jumlah \\
\hline 1 & Belakang Padang & 9673 & 9556 & 19229 \\
\hline 2 & Bulang & 5246 & 4678 & 9924 \\
\hline 3 & Galang & 8412 & 7311 & 15723 \\
\hline
\end{tabular}

Dari jumlah penduduk di Tabel 1 jika diperkirakan oleh Dinas Lingkungan Hidup Kota Batam saat ini 1 jiwa memproduksi sampah sebanyak 1 kilogram Kecamatan Belakang Padang akan memproduksi 19229 Kg/Hari, Kecamatan Bulang 9924 Kg/Hari, dan Kecamatan Galang sebanyak $15723 \mathrm{Kg} / \mathrm{hari}$. Penelilti juga memusatkan perhatian pada Kecamatan Belakang Padang dikarenakan estimasi jumlah sampah per hari lebih besar dari Kecamatan lainnya seperti yang terlihat pada Grafik 1.

Grafik 1 Estimasi Jumlah Sampah Per Hari Kecamatan Belakang Padang, Bulang, dan Galang Tahun 2018

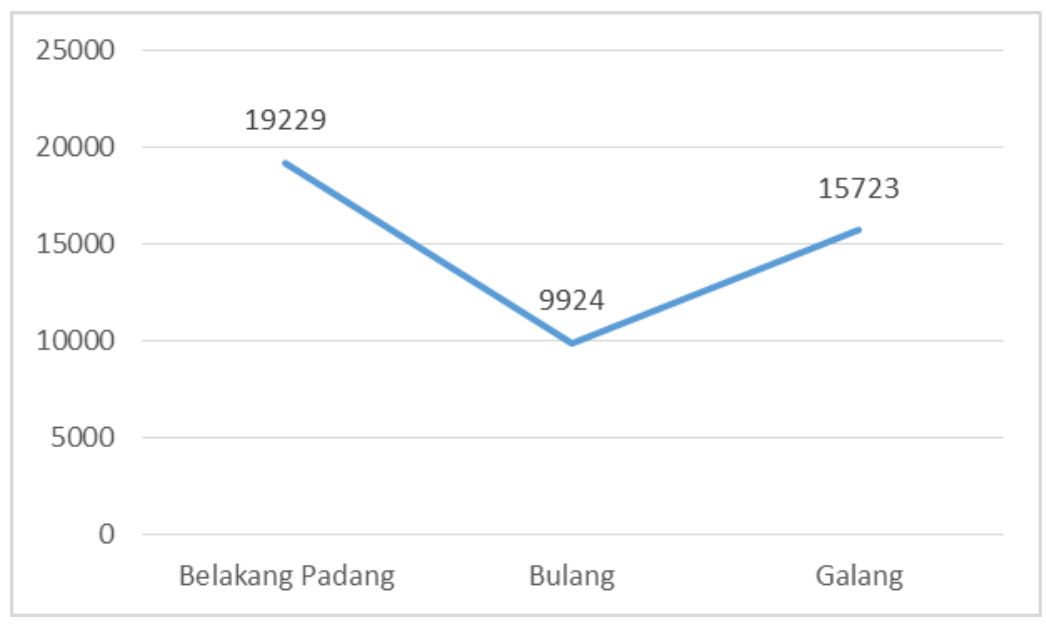

Sumber: diolah peneliti

Kecamatan Belakang Padang terdiri dari 108 pulau yang terdiri dari 43 pulau yang telah dihuni dan 65 pulau belum dihuni. Karena geografis yang berupa pulau-pulau tersebut rawan sekali pembungan sampah di laut. Sampah di laut akan bertahan hingga lebih dari 1000 tahun yang akan mengganggu kehidupan biota-biota yang hidup di dalamnya. Sampah plastik yang memiliki dampak buruk bagi lingkungan dikuatkan oleh 
pendapat ilmuwan dari SCIRO (Commonwealth Scientific and Industiral Research Organization) dan Imperial College London mengatakan bahwa 90\% dari burung laut terdapat plastik di perutnya. Diperkirakan jumlah tersebut akan bertambah menjadi 99 persen pada tahun $2050 .^{2}$

Pada Kecamatan Belakang Padang permasalahan sampah menjadi permasalahan tersendiri jika pulau-pulau tersebut tidak memilih sistem pengelolaan sampah yang baik, apalagi pulau tersebut berbatasan langsung dengan Singapura. Saat pertama kali datang berkunjung. Pengunjung akan melihat sampah memenuhi bibir pelantar di pelabuhan hingga ke sekitar pasar rakyat dan lapangan. Seperti yang terlihat pada Gambar 1 tentang Sampah di Pasar Kecamatan Belakang Padang dibawa ini.

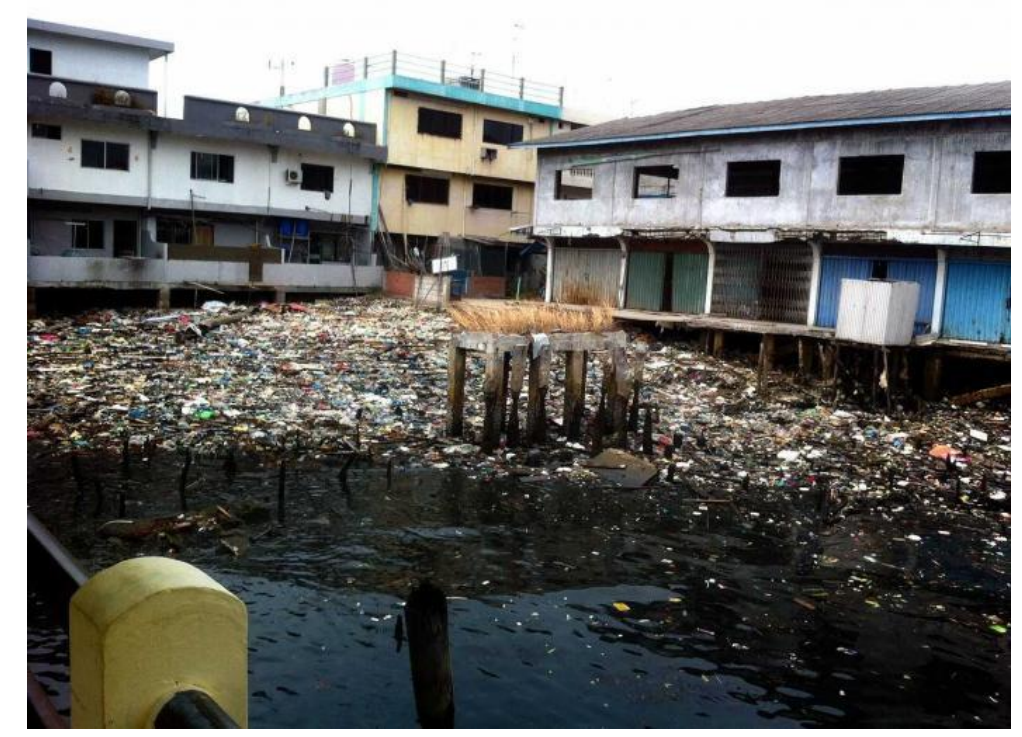

Gambar 2 Sampah di Pasar Kecamatan Belakang Padang

Permasalahan ini juga dikuatkan oleh keterangan wawancara Bapak Wagiman selaku Sekretaris Camat Belakang Padang yang mengakui kesulitan dalam pengelolaan sampah di karenakan tidak tersedianya fasilitas pembantu:

"Kami tidak ada kapal untuk menyisir sampah. Kapal yang ada rusak" (Wagiman: 12/3/2017)

\footnotetext{
${ }^{2}$ Sulistya Ekawati. 2016. Mengkritisi Kebijakan Penanganan Kantong Plastik di Indonesia. Pusat Penelitian dan Pengembangan Sosial, Ekonomi, Kebijakan dan Perubahan Iklim: Volume 10 No 6. Hal 1
} 
Tentu permasalahan pengangkutan sampah di Kecamatan Belakang Padang akan menjadi masalah apalagi terdapat kelurahan-keluaran yang berkontur pulau-pulau. Dalam penelitian ini peneliti akan melihat implementasi program pengangkutan sampah di Kecamatan Belakang Padang yang dilaksanakan oleh Kecamatan Belakang Padang dan mitra.

\section{METODOLOGI (Material dan Metode)}

Penelitian ini dilaksanakan pada bulan April - November 2019. Tempat penelitian di Kecamatan Belakang Padang. Tempat lain di lokasi Mitra pengangkutan sampah. Jenis penelitian ini mengunakan pendekatan kualitatif dengan analisa deskriptif. Metode deskriftif diartikan sebagai prosedur pemecahan, masalah yang diselidiki dengan mengambarkan objek yang diteliti, seperti idividu, lembaga, masyarakat dan lain-lain, pada saat sekarang berdasarkan fakta-fakta yang tampak atau sebagaimana adanya. ${ }^{3}$

Data yang dikumpulkan untuk penelitian ini berupa data primer dan data sekunder. Adapun sumber data tersebut, yaitu :

1. Data Primer adalah data yang dihasilkan untuk memenuhi kebutuhan penelitian. Data dikumpulkan secara langsung dilapangan dari responden dengan wawancara dan observasi lapangan di Kecamatan Belakang Padang.

2. Data Sekunder adalah daa yang didapat dari studi kepustakaan dari dokumen-dokumen Kecamatan Belakang Padang, media massa, media elektronik, serta sumber-sumber tertulis lainnya.

Pengumpulan data dilakukan untuk memperoleh informasi yang dibutuhkan dalam rangka mencapai tujuan penelitian. Data dikumpulkan dari sampel yang telah ditentukan sebelumnya. Sampel tersebut terdiri atas sekumpulan unit analisis sebagai sasaran penelitian. Pengumpulan data dalam penelitian ini mengunakan teknik purposive sampling. Teknik ini digunakan untuk memperoleh informan data organisasi atau kelompok yang terbatas untuk menemukan informan yang tepat.

\footnotetext{
${ }^{3}$ Nawawi, Hadari. 1992. Metode Penelitian Bidang Sosial. Yogyakarta: Press. Hal. 63
} 
Teknik pengulumpan data ${ }^{4}$ :

1. Observasi adalah belajar tentang perilaku dan makna dari perilaku tersebut.

2. Wawancara, adalah merupakan pertemuan dua orang untuk bertukar informasi dan ide melalui tanya jawab, sehingga dapat dikonstruksikan makna dalam suatu topik tertentu

3. Dokumentasi adalah catatan peristiwa yang sudah berlalu. Dokumen bisa berbentuk tulisan, gambar, atau karya-karya monumental dari seseorang.

Penelitian ini menggunakan teknik analisa yaitu :

1. Data Reduction (Reduksi Data) yaitu proses pemilihan, pemusatan perhatian pada penyederhanaan, pengabstrakan, dan transformasi data kasar yang muncul dari catatan-catatan tertulis dari lapangan.

2. Data Display (Penyajian Data) yaitu sekumpulan informasi tersusun yang memberi kemungkinan adanya penarikan kesimpulan dan pengambilan tindakan.

3. Conclusion Drawing/verification (Penarikan Kesimpulan / verifikasi yaitu penarikan arti data yang telah ditampilkan.

\section{PEMBAHASAN}

William Dunn menyebutkan implementasi kebijakan (policy implementation) adalah pelaksaan pengendalian aksi-aksi kebijkan di dalam kurun waktu tertenu. Program pengankutan sampah di Kecamatan Belakang Padang sejatinya telah diimplementasikan langsung dikomandoi oleh Camat. Pada penelian ini implementasinya akan diliat dari sudut padang teori yakni Pertama, Indikator masukan kebijakan (Policy Input), dan Kedua, Indikator keluaran Kebijakan (Policy Output).

1. Indikator Masukan Kebijakan

a. Peraturan Daerah

Peraturan Daerah yang mengatur adalah Peraturan Kota Batam No 11 Tahun 2013 Tentang Pengelolaan Sampah. Pada peraturan ini Pengelolaan Sampah

\footnotetext{
${ }^{4}$ Sugiyono. 2009. Metode Penelitian Kuantitatif, Kualitatif, dan R\&D. Bandung: Alfabeta. Hal. 224-240
} 
terdiri dari (1) Pemilahan sampah; (2) Pengumpulan sampah; (3) Pengangkutan sampah; (4) Pengolahan sampah; dan (5) Pemprosesan akhir sampah. Dalam penelitian ini penulis membatasi pada persoalan pengangkutan sampah.

Pengangkutan sampah adalah pengangkutan sampah dalam bentuk membawa sampah dari sumber dan/atau dari tempat penampungan sampah sementara menuju ke tempat pensmpungan akhir.

Pengangkutan sampah sendiri berdasarkan Perwako ini pada pasal 22 adalah sebebagai berikut:

1) Pengangkutan sampah dilaksanakan dengen sistem langsung dan tidak langsung;

2) Pengangkutan sampah selain dilakukan oleh Dinas, dapat dilakukan oleh pengelola kawasan permukiman dan pihak ketiga (mitra);

3) Pengangkutan sampah dilakukan dengan membawa sampah dari sumber sampah ke TPS/TPST/TPA, atau dari TPS/TPST ke TPA;

4) Pemerintah Daerah menyediahkan Stasiun Peralihan Antara untuk mendukung kegiatan pengangkutan sampah;

5) Pengangkutan sampah dilaksanakan dengan cara yang menjamin tetap terpilahnya sampah berdasarkan jenis sampah, hingga ke TPS/TPST/TPA, dan tidak tercecer di perjalanan selama dalam proses pengangkutannya; dan

6) Sampah diangkut dengan menggunakan alat pengangkut sampah yang memenuhi standar sesuai dengan ketenteuan peraturan berlaku,

Pada penelitian Solihin dan Ronald (2018) menyatakan bahwa cakupan yang dikelola oleh Dinas Lingkungan Hidup Kota Batam hanya merupakan wilayah Darat (mainland) saja kecuali Bulang, Galang dan Belakang Padang. Pada pelaksanaan pengangkutan sampah di wilayah Belakang Pedang langsung dibebankan kepada Kecamatan dengan dibantu oleh petugas pengankutan sampah.

b. Organisasi Pelaksana

Adapun organiasi pelaksana dalam pengangkutan sampah di Kecamatan Belakang Padang terdiri dari : 
1) Kecamatan

Pada pertengahan tahun 2016 kecamatan mendapat limpahan tugas kebersihan di wilayah teritorial masing-masing yang diemban oleh Kepala Seksi Ketertiban dan Umum untuk melaksanakan pengangkutan sampah dari rumah ke TPS sementara di kecamatan masing-masing dengan berkoordinasi dengan RT/RW.

2) Satuan Petugas Pengangkutan Sampah Kecamatan Belakang Padang

Pihak kecamatan mendapatkan limpahan tenaga yang diberikan peluang untuk mempekerjakan pegawai kontrak untuk menjadi Satuan Petugas Pengangkutan Sampah di Kecamatan Belakang Padang.

c. Sumberdaya

1) Sumberdaya Manusia

Sejak tahun Desember 2016 Perwako tentang pelimpahan kewenangan kepada kecamatan. Pengelolaan Tempat Pembuangan Akhir (TPA) adalah milik pemerintah. Personil satgas pengangkutan sampah di Kecamatan Belakang Padang terdiri dari 13 orang yang diambil dari masyarakat setempat yang terdiri 1 orang supir Pick Up, 2 orang kernet Pick Up, 2 orang Petugas Becak Sampah, dan 8 Petugas Kebersihan Jalan.

Adapun sumberdaya manusia yang ada di Kecamatan Belakang Padang adalah:

Tabel 2

Satuan Petugas Pengangkutan Sampah Kecamatan Belakang Padang

\begin{tabular}{|l|l|l|}
\hline No & Nama & Posisi \\
\hline 1 & Izhar & Petugas Kebersihan Jalan \\
\hline 2 & Habib Nur & Supir Pick Up \\
\hline 3 & Karsono & Petugas Becak Sampah \\
\hline 4 & Hendra Siswanto & Kernet Pick Up \\
\hline 5 & Misriono & Petugas Kebersihan Jalan \\
\hline
\end{tabular}




\begin{tabular}{|l|l|l|}
\hline 6 & Sadan & Petugas Kebersihan Jalan \\
\hline 7 & Untung Bin Kamsudin & Petugas Kebersihan Jalan \\
\hline 8 & Hariyadi & Petugas Kebersihan Jalan \\
\hline 9 & Rustono & Petugas Kebersihan Jalan \\
\hline 10 & Mohd Soleh Al Deniel Balu & Petugas Kebersihan Jalan \\
\hline 11 & Kamarudin & Kernet Pick Up \\
\hline 12 & Abdul Hadi & Petugas Becak Sampah \\
\hline 13 & Harris Irwansyah & Petugas Kebersihan Jalan \\
\hline
\end{tabular}

Sumber: Data Kecamatan Belakang Padang 2019

2) Fasilitas

Adapun fasilitas yang dimiliki oleh Kecamatan Belakang Padang untuk pengangkutan sampah antara lain adalah berupa alat angkut 2 becak motor/kaisar 1 beroperasi dengan baik namun 1 dalam kondisi rusak, dan 1 mobil pick up pengangkutan sampah juga rusak.

Tabel 3

Fasilitas Petugas Pengangkutan Sampah Kecamatan Belakang Padang 2018

\begin{tabular}{|l|l|l|l|}
\hline No & Fasilitas & Jumlah & Keterangan \\
\hline 1 & $\begin{array}{l}\text { Tempat Pembuangan } \\
\text { Akhir }\end{array}$ & 1 & Saat ini Kondisi hamper penuh \\
\hline 2 & $\begin{array}{l}\text { Tempat Pembuangan } \\
\text { Sementara }\end{array}$ & 1 & $\begin{array}{l}\text { Jumlahnya sangat sedikit } \\
\text { terdapat di pasar Belakang } \\
\text { Padang }\end{array}$ \\
\hline 3 & Mobil Pick Up & 1 & Mobil pick up rusak \\
\hline 4 & Becak Motor/Tosa & 2 & 1 motor rusak \\
\hline 5 & Mesin Pencacah Kompos & 1 & Mesin pencacah tidak hidup \\
\hline 6 & Peralatan Kebersihan & ada & $\begin{array}{l}\text { Peralatan kebersihan ada, } \\
\text { namun dibutuhkan pengadaan } \\
\text { mantel untuk petugas bekerja }\end{array}$ \\
\hline
\end{tabular}




\begin{tabular}{|l|l|l|l|}
\hline & & & disaat hujan \\
\hline 7 & Boat & $\begin{array}{l}\text { Tidak } \\
\text { Ada }\end{array}$ & $\begin{array}{l}\text { Tidak adanya boat operasional } \\
\text { milik pemerintah membuat } \\
\text { sampah yang ada dilaut tidak } \\
\text { dapat dilakukan pengumpulan }\end{array}$ \\
\hline
\end{tabular}

Sumber: Peneliti, 2019

Tempat Pembuangan Akhir saat ini dalam kondisi hampir penuh seperti di gambarkan pada Gambar dibawah ini, menurut peneliti TPA bisa dirapikan kembali namun membutuhkan teknologi untuk memadatkan sampah.

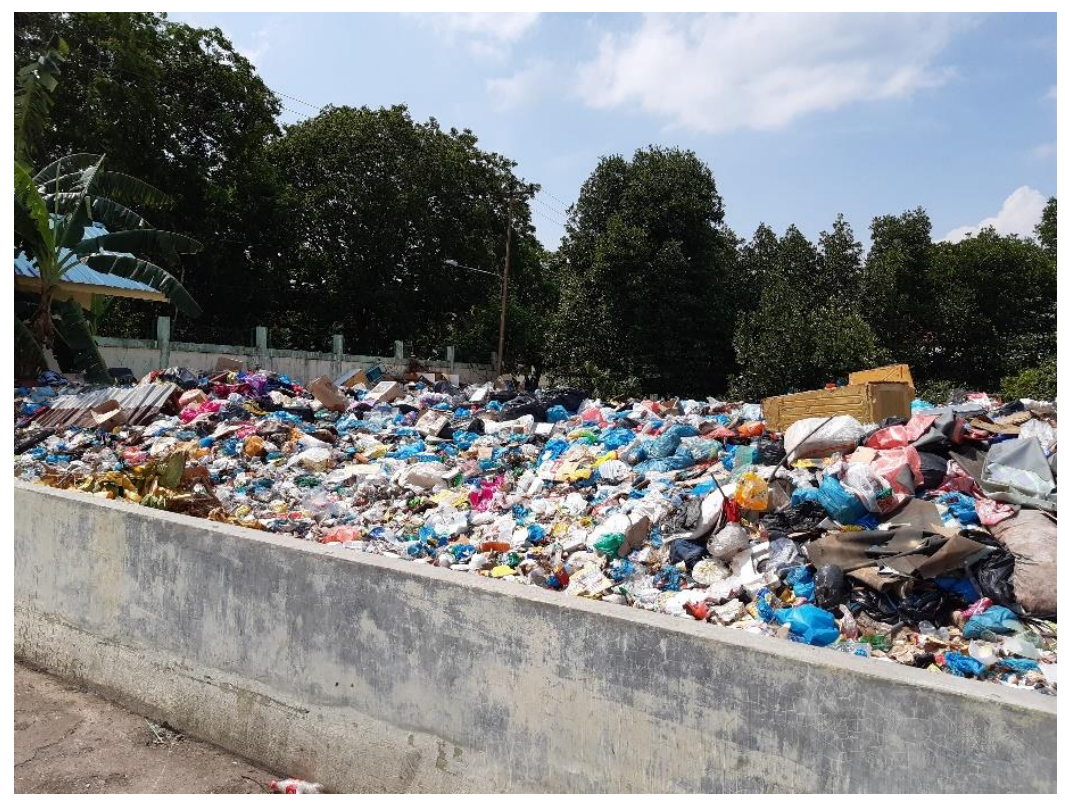

Gambar 3 Kondisi Sampah di TPA Kecamatan Belakang Padang

Menurut Pak Yanto (54) Kecamatan Belakang Padang memiliki 1 Tempat Pembuagan Akhir (TPA) seluas $277 \mathrm{~m}^{2}$ yang keadaanya sudah penuh sampah.

"Tempat pembuangan sampah TPA hanya ada 1, tempat pembuangan sampah sementara TPS hanya ada 1 di pasar. Luas TPA kita ada $277 \mathrm{~m}^{2}$ dan itupun TPAnya sudah penuh sampah." (11 Juli 2019)

Tempat Pembuangan Sementara di Belakang Padang ada 1 titik terletak di pasar Belakang Padang. Bak sampah sebagai tempat penitipan / 
pembuangan sampah di 2 kelurahan awalnya diberikan oleh pihak pemerintah untuk 3 rumah satu tempat sampah, namun banyak yang hilang atau rusak. Saat ini warga secara swadaya mengadakan tempat sampah di depan rumah mereka. Masyarakat Belakang Padang rata-rata hanya memiliki 1 jenis tempat sampah yang berarti umumnya di Belakang Padang tidak terjadi proses pemilahan sampah sejak di rumah tangga.

Bapak Yanto (54) selaku Petugas Pengangkutan Sampah di Kecamatan Belakang Padang menyatakan bahwa mereka dilengkapi oleh sarung tangan, jas hujan, cangkul. Namun pengadaan untuk alat-alat operasional ini hanya diadakan dalam 1 tahun sekali. Berikut penggalan wawancara dengan Bapak Yanto:

"Sedangkan peralatan angkat sampah ada seperti sarung tangan, jas hujan, cangkul diganti hanya 1 tahun sekali." (11 Juli 2019)

Hasil observasi peneliti kelapangan menemukan bahwa 1 becak motor rusak dan 1 mobil pick up juga dalam keadaan rusak yang bisa dilihat pada gambar dibawah ini. Namun dalam pelaksanaannya Satuan Petugas mengunakan mobil lain untuk pengangkutan sampah.

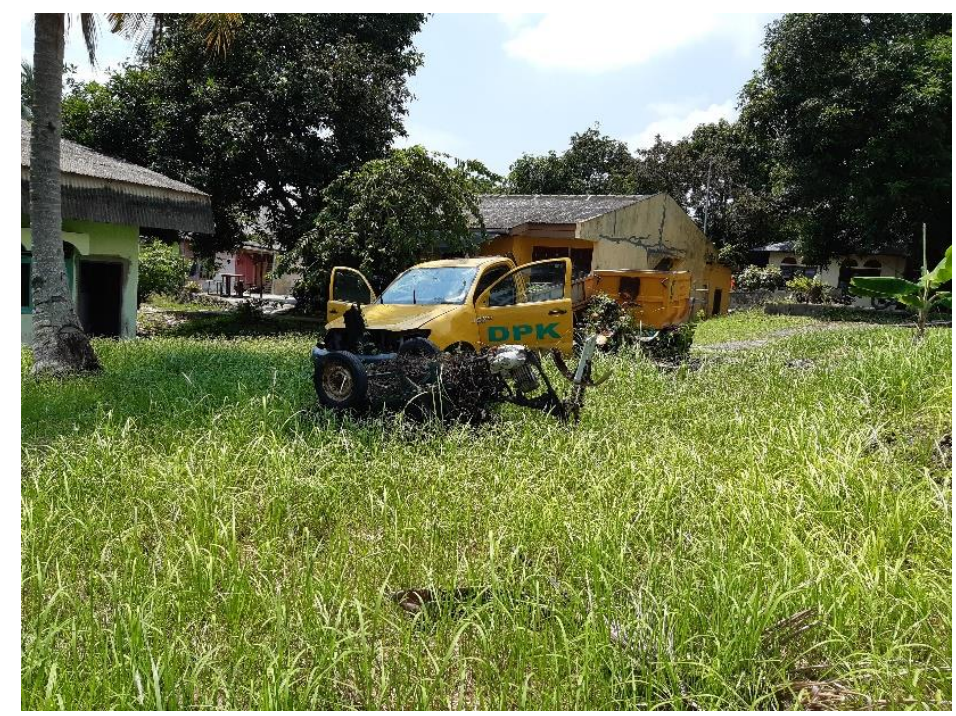

Gambar 4 Mobil dan BeCak Motor Dalam Keadaan Mangkrak

Permasalahan mobil rusak pada gambar diatas tentu menjadi hambatan dalam implementasi pengangkutan sampah di Kecamatan 


\section{Belakang Padang. Camat Belakang Padang Bapak Yudhi Admaja} mengatakan perna terjadi penumpukan sampah dikarenakan mobil rusak.

"Pada saat mobil mengalami kerusakan perna terjadi sempat 2 hari mobil tidak operasi sehingga terjadi penumpukan di TPS.” (2 Juli 2019)

Pendapat diatas juga diperkuat oleh Bapak Yanto (54) selaku Petugas Pengangkutan Sampah Kecamatan Belakang Padang, beliau menyebutkan pengangkutan sampah terkendala juga karena mobil dan tosa (becak motor) rusak dan terkadang lambat dilakukan perawatan.

"Kendala dalam pengangkatan sampah adalah mobil rusak 3) Anggaran kadang lama baru benar, motor tosa rusak." (11 Juli 2019)

Adapun anggaran untuk operasional pengangkutan sampah yakni terdiri dari Gaji Pegawai Honor, dana perawatan fasilitas, dana operasional.

Tabel 4 Upah Satuan Petugas Kebersihan Tahun 2018

\begin{tabular}{|r|l|l|r|r|r|}
\hline & & satuan & volume & \multicolumn{1}{l|}{ orang } & Jumlah \\
\hline 1 & Upah Kernet Sampah & 3511200 & 12 & 2 & 84268800 \\
\hline 2 & Upah Petugas Becak Sampah & 3511200 & 12 & 2 & 84268800 \\
\hline 3 & Upah Supir Pick Up Sampah & 3511200 & 12 & 1 & 42134400 \\
\hline 4 & Upah Petugas Kebersihan Jalan & 3511200 & 12 & 8 & 337075200 \\
\hline & & & & Jumlah & 547747200 \\
\hline
\end{tabular}

Sumber : Kecamatan Belakang Padang, 2019

Dari Tabel diatas selama 12 Bulan untuk upah 13 Satgas Kecamatan Belakang Padang mengeluarkan anggaran Rp 547.747.200,-. Data diatas juga diperkuat oleh Camat Belakang Padang yakni Bapak Yudhi Atmadja:

"Terkait pelimpahan kewenangan termasuk pelimpahan penganggaran, termasuk penggajian satgas/tenaga, operasional gaji satgas perbulan sekitar 3,4 juta/3,5 juta sama dengan gaji satgas yang ada di Batam. Status pegawai satgas pengangkutan sampah adalah kontrak, dan mereka berkontrak dengan pihak kecamatan dengan kontrak per 1 tahun. Untuk jaminan BPS petugas pengangkutan sampah hanya ditanggung $2 \%$ oleh pihak pemerintah kecamatan.” 
Sedangkan menurut Pak Yanto (54) petugas pengangkutan sampah di Kecamatan Belakang Padang mereka bersih penerima upah sebesar 3,3 juta dipotong anggaran BPJS Kesehatan.

"Terkait gaji satgas, petugas pengangkutan sampah perbulan bersih 3,3 juta, BPJS Kesehatan ada." (11 Juli 2019)

Tabel 5 Anggaran Peralatan Kebersihan

\begin{tabular}{|l|r|r|r|}
\hline & volume & harga satuan & jumlah \\
\hline Cangkul & 4 & 79000 & 316000 \\
\hline Sapu Lidi bertangkai & 6 & 20000 & 120000 \\
\hline Garuk & 5 & 75000 & 375000 \\
\hline Sabun Cuci & 10 & 24000 & 240000 \\
\hline Sarung Tangan & 13 & 55700 & 724100 \\
\hline Baju Kaos lengan panjang & 13 & 150000 & 1950000 \\
\hline Topi & 13 & 40000 & 520000 \\
\hline & & Total & 4245100 \\
\hline
\end{tabular}

Sumber: Data Kecamatan Belakang Padang 2019

Untuk peralatan kebersihan Satgas telah dilengkapi dengan peralatan seperti cangkul, sapu, Garuk, Sabun, Sarung Tangan, Baju, dan Topi seperti yang sudah dianggarkan pada table diatas berjumlah Rp 4.245.100,- . Namun sebaiknya sarung tangan untuk diadakan lebih banyak mengingat masa pakainya yang tidak mungkin dipakai untuk 1 tahun, selanjutnya petugas juga harus dilengkapi dengan masker, jas hujan dan sepatu boat untuk bekerja diwaktu hujan.

Tabel 6 Premi Asuransi

\begin{tabular}{|l|r|r|l|}
\hline & Volume & Harga Satuan & Jumlah \\
\hline Premi Asuransi & 13 & 114000 & 1482000 \\
\hline & & Total & 1482000 \\
\hline
\end{tabular}

Sumber: Data Kecamatan Belakang Padang 2019

Petugas pengangkutan sampah juga telah dilengakpi premi asuransi BPJS Ketenagakerjaan yang dibebankan kepada kedua belah pihak yakni sebesar Rp 114.000,-/bulan.

Tabel 7 Belanja Perawatan Kendaraan Bermotor

\begin{tabular}{|r|r|r|r|}
\hline & & $\begin{array}{r}\text { Harga } \\
\text { Satuan }\end{array}$ & Jumlah \\
\hline
\end{tabular}




\begin{tabular}{|l|r|r|r|}
\hline Oli Mesin Sepeda Motor & 12 & 30000 & 360000 \\
\hline Ban Luar Depan & 1 & 360000 & 360000 \\
\hline Ban Luar Belakang & 4 & 420000 & 1680000 \\
\hline Accu Sepeda Motor & 1 & 289500 & 289500 \\
\hline & & Total & 2689500 \\
\hline
\end{tabular}

Sumber: Data Kecamatan Belakang Padang 2019

Adapun untuk biaya perawatan kendaaraan bermotor digunakan untuk membeli oli mesin, ban, dan accu untuk 1 tahun berjumlah Rp 2.689.500,- .

Sedangkan untuk anggaran belanja bahan bakar minya dan gas dianggarkan sebanyak $\mathrm{Rp}$ 17.592.960,- dengan rincian pemakaian 1 hari sebanyak 7 liter bensin berjenis Premium.

Tabel 8 Belanja Bahan Bakar Minyak dan Gas
\begin{tabular}{|l|r|r|r|}
\hline & volume & harga satuan & jumlah \\
\hline $\begin{array}{l}\text { Premium (1 x 7 liter } \\
\text { x 29 hari x 12 } \\
\text { bulan) }\end{array}$ & 2352 & & \\
\hline & & Total & 17592960 \\
\hline
\end{tabular}

Sumber: Kecamatan Belakang Padang 2019

\section{Indikator Keluaran Kebijakan}

a. Akses

Akses membuang sampah di Kecamatan Padang warga dapat membuang sampah tersebut ke Tempat sampah di depan rumah yang nanti diangkat oleh Petugas Pengangkut Sampah menuju ke Tempat Pembuangan Akhir (TPA). Hal ini diperkuat oleh pendapat Pak Yano (54 Tahun) Petugas Pengangkutan Sampah :

"Pembuangan sampah warga buang sampah di depan rumah, di depan rumah warga ada tong-tong sampah yang dibuat oleh warga sendiri." (11 Juli 2019)

Di Kelurahan Sekanak Raya menurut Bapak Royanto (56) warga dapat membuang sampah di Tempat Sampah atau di dalam kantong plastik yang nanti diangkut oleh petugas pengangkutan sampah setiap hari kecuali hari minggu. Sampah yang di anggkut dalam keadaan tidak terpilah. 
Di Sekanak Raya buang sampah di depan rumah di tong sampah atau kantong plastik nanti ada mobil sampah yang ambil sampah di depan rumah, kecuali hari minggu. Biasanya sampah dibuang dalam satu tong sampahnya dicampur. (17 Juli 2019)

Untuk biaya pengangkutan sampah menurut Bapak Royanto (56) pemerintah tidak melakukan pemungutan biaya.

Untuk biaya pengangkatan sampah setiap rumah tidak dipungut biaya alias gratis. Program pengangkatan sampah harus dilanjutkan karena sangat penting. (17 Juli 2019)

Menurut $\mathrm{Bu}$ Harnina (48) akses pembuangan sampah mereka tinggal meletakkan didepan rumah yang nantinya akan diangkat oleh petugas pengankutan sampah, namun untuk sampah basah mereka masih terbiasa membuangnya ke laut.

"Tempat pembuangan sampah kering biasanya ditaruh di depan rumah nanti ada petugas yang ambil di depan, tapi kalau sampah basah dibuang ke laut karena kalau tidak dibuang cepat takutnya bau gak sedap.” (17 Juli 2019)

Menurut Ibu Windi (45) Warga Kelurahan Tanjung Sari akses mereka membuang sampah di kantong plastik yang dimasukkan dalam ember lalu setiap pagi sampah diangkat oleh petugas pengangkutan sampah. Namun Ibu windi menyayangkan tidak tersediahnya Tempat Pembuangan Sementara di lingkungannya.

"Pembuangan sampah setiap hari biasanya kita buang sampah di kantong plastik, setiap pagi sampah diangkat oleh petugas pengangkutan sampah. Untuk jenis sampah semuanya digabung jadi satu. . Untuk tempat sampah sementara TPS disini tidak ada, adanya di pasar dekat pelabuhan.” (16 Juli 2019)

Selain itu Pak Rusman juga mengeluhkan kurangnya tong sampah di Kecamatan Belakang Padang yang saat ini satu tong sampah jaraknya 5 meter. Jadi masyarakat tidak memiliki tempat sampah masing-masing. Selain itu kendala sampah laut tidak diangkut dikarenakan Kecamatan tidak memiliki Boat pengankutan sampah. 
"Saat ini kita kekurangan tong sampah, 1 tong sampah jaraknya 5 meter lebih, karena kurang tong sampah jadi masyarakat malas jauh-jauh buang sampah. Untuk alat angkut sampah sangat kurang sekali dengan jumlah sampah yang banyak. untuk sampah di laut pemerintah tidak punya boat." (17 Juli 2019)

Pemerintah Kecamatan Belakang Padang tidak melakukan pemungutan biaya pengangkutan sampah. Harapan kedepan ada bantuan tong sampah untuk masyarakat. Berdasarkan wawancara dengan Camat Belakang Padang Yudhi Atmaja juga membenarkan bahwa sebagaian besar warganya masih membuang sampah di laut. Sudah dilakukan sosialisasi namun tidak diiringi oleh perubahan perilaku pembuangan sampah.

Akses pembuangan sampah bagi masyarakat untuk saat ini masih sebagaian besar 50\% buang sampah di laut, dan di darat $50 \%$ buang sampah di TPA yang telah disediakan disetiap kampung. Sebagian besar warga masih kurang kesadaran dalam membuang sampah. Karena masih banyak masyarakat yang masih membuang sampah ke laut terutama yang tinggal di daerah pesisir. (2 Juli 2019)

Masalah pembuangan sampah di pesisir, masyarakat membuang sampah sembarangan di laut, bagi masyarakat membuang sampah di laut adalah hal yang biasa, sehingga pola kehidupan sehari-hari mereka sudah terbiasa membuang sampah di laut secara turun-temurun, bagi mereka kalau buang sampah di darat itu sesuatu yang menyulitkan bagi mereka. 


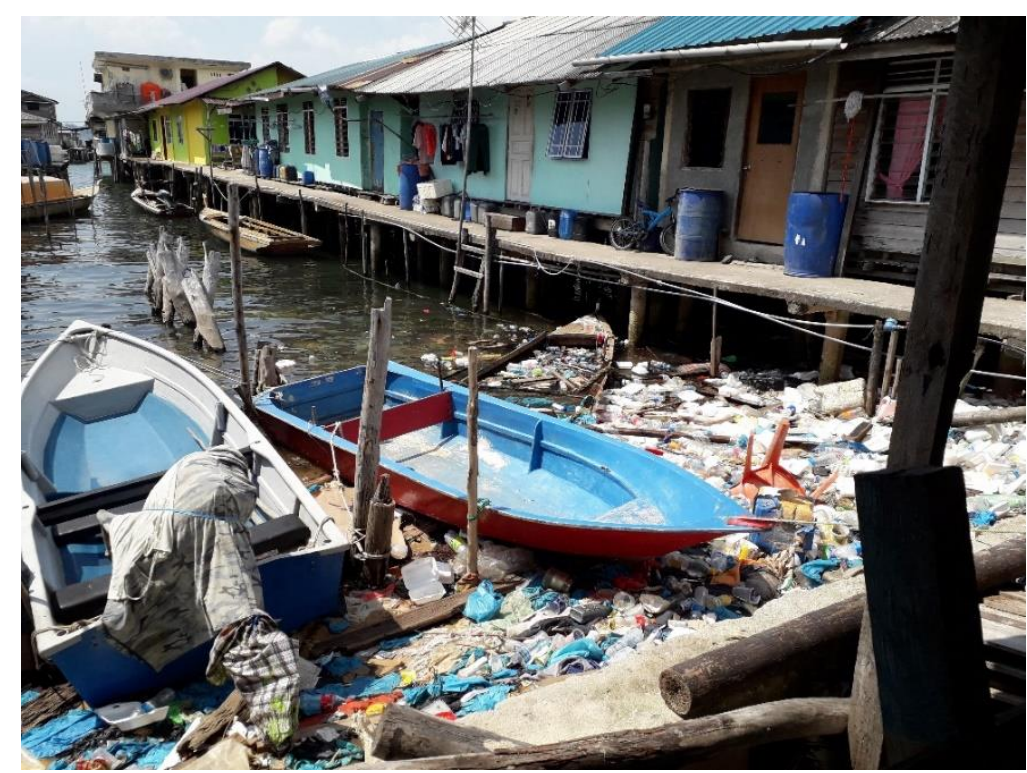

Gambar 5 Timbunan Sampah di Kampung Bugis Kecamatan Belakang Padang

Menurut Pak Yhudi Atmadja Camat Belakang Padang menejelaskan bahwa merubah pola pikir mereka sangat sulit, lewat berbagai kegiatan sosialisasi bahwa jangan membuang sampah di laut, namun tetap saja masyarakat membuang sampah di laut karena sudah menjadi kebiasaan dan pola pikirnya sudah terbentuk seperti itu. Mereka malas buang sampah di TPS dekat jalan besar, bagi mereka ribet lebih mudah bagi mereka lempar aja sampah ke laut, sampah rumah tangga, sampah kayu, kaya dan plastik. Penumpukan sampah di bibir pantai itu adalah sampah warga, dan juga ada sampah kiriman dari Batam, ada musim-musimnya. Untuk kontak sampah di pulau-pulau dan pesisir belum tersedia.

Penumpukan sampah volume paling tinggi di wilayah pasar dan pelabuhan. Di Belakang Padang ada 10 titik atau bak sampah sebagai tempat penitipan / pembuangan sampah sementara TPS di 2 kelurahan. Pengangkatan sampah di laut diangkat menggunakan jarring saat air pasang, setelah dibersihkan di laut, namun sampah datang lagi begitu seterusnya. Untuk membersihkan sampah di laut kita sangat membutuhkan speed boats, sampai saat ini kita belum punya speed boats sudah diajukan ke pemerintah namun 
sampai saat ini belum direalisasikan. Pihak kecamatan sudah kewalahan mengatasi sampah di laut.

Pengangkatan sampah di laut diangkat menggunakan jarring saat air pasang, setelah dibersihkan di laut, namun sampah datang lagi begitu seterusnya. Untuk membersihkan sampah di laut kita sangat membutuhkan speed boats, sampai saat ini kita belum punya speed boats sudah diajukan ke pemerintah namun sampai saat ini belum direalisasikan. Pihak kecamatan sudah kewalahan mengatasi sampah di laut.

Menurut Pak Sahib (61) warga Kelurahan Tanjung Sari menyatakan bahwa pemerintah kecamatan harus melengkapi tempat sampah yang cukup.

"Harus ada tempat sampah yang cukup, dan harus ada tenaga yang angkat sampah supaya sampah tidak numpuk. Sampah dari laut kami bersama warga lain angkat ke darat, tapi tidak ada fasilitas dan petugas yang angkat ketempat pembuangan sampah TPS/TPA karena kekurangan alat angkut dan petugas, jadi sampah yang kami angkat dari laut akhirnya berserakat di darat karena banyak anajing, ayam yang serakkan sampah." (17 Juli 2019)

Selanjutnya menurut Pak Sahib (61) mengeluhkan petugas pengankut sampah yang hanya mengankut sampah yang ada di darat saja, sedangkan sampah dilaut sangat banyak tidak diangkut.

"Sepanjang pantai banyak sampah plastik yang tidak terurus, dan tidak ada petugas pengangkatan sampah mereka hanya di wilayah darat saja." (17 Juli 2019)

b. Frekuensi

Frekuensi pengakutan sampah di Kecamatan Belakang Padang dijawal kan 6 hari kerja yakni dari Senin - Sabtu, dalam 1 hari mereka sanggup mengangkut 3 kali namun petugas Kebersihan biasanya akan tetap bekerja menjelang hari-hari besar untuk menjaga kebersihan.

Berdasarkan wawancara dengan Pak Camat Yudhi Atmaja 
"Frekuensi pengakutan sampah di di Kelurahan Tanjung Sari dan Sekanak Raya Belakang Padang dilakukan setiap hari dari SeninSabtu, dan untuk hari mingu tergantung event. Pengangkutan sampah selalu tepat waktu, kecuali mobil mengalami kerusakan perna terjadi sempat 2 hari mobil tidak operasi sehingga terjadi penumpukan di TPS.” (2 Juli 2019)

Menurut Pak Yanto (54) Petugas Pengangkutan Sampah di Kecamatan Belakang Padang frekuensi pengangkutan sampah di Kecamatan Belakang Padang dilakuakan 1 hari tiga kali pengangkutan meliputi dua kelurahan.

"Pengangkatan sampah di Belakang Padang 1 hari tiga kali pengangkutan, yang meliputi Sekanak Raya dan Tanjung Sari." (11 Juli 2019)

Untuk pengangkutan sampah khusus di jalan kecil atau ganggang sepit sampat diangkat menggunakan motor becak Tosa. Banyak sampah yang diangkut 1 mobil dan 2 motor Tosa, pengangkutan sampah dari jam 5 subuh sampai jam 11 atau jam 12 siang tergantung seberapa banyak sampah yang diangkut.

\section{c. Cakupan}

Cakupan wilayah pengangkutan sampah yang dicover oleh Pemerintah Kecamatan Belakang Padang hanya 2 wilayah kelurahan yaitu; Sekanak Raya dan Tanjung Sari. Ini juga senada dengan keterangan wawancara dibawah ini pelayanan pengangkutan sampah di Kecamatan Belakang Padang hanya mengankut sampah di 2 kelurahan, sedangkan 4 kelurahan lain tidak.

Hal ini diperkuat oleh pernyataan dari Camat Belakang Padang yakni Bapak Yudhi Atmadja:

"Wilayah operasional pengangkutan sampah di Belakang Padang meliputi 2 kelurahan dari 6 kelurahan yang ada, 2 kelurahan yang di cover oleh kecamatan dalam hal pengangkutan sampah meliputi; Kelurahan Sekanak Raya dan Tanjung Sari di wilayah daratan Belakang padang dengan total penduduk 12.000, sedangkan 4 kelurahan lainnya yang belum tercover oleh pemerintah kecematan 
dalam pengangkutan samapah yaitu meliputi 4 kelurahan di wilayah pulau-pulau; Kelurahan Pecong, Kasu, Pemping, Pulau Terong.” (2 Juli 2019)

d. Bias

1) Tidak Terlayani Masyarakat 4 Kelurahan

Tidak terlayaninya 4 kelurahan yang berada di pulau merupakan kekurangan yang sangat luar biasa. Dikarenakan semangat otonomi daerah adalah bagaimna pelayanan bisa menjangkau sampai kedaerah. Ada empat kelurahan yang tidak dilayani pengankutan sampah di Kecamatan Belakang Padang yakni Kelurahan Pecong, Kasu, Pemping, Pulau Terong. Hasilnya di 4 kelurahan tersebut masih banyak masyarakat yang membuang sampah ke laut.

2) Tidak Melakukan Pengangkutan Sampah di Laut

Pak Royanto (56) warta kelurahan Sekanak Raya menjelaskan bahwa sampah di laut tidak diangkat oleh pihak petugas pengangkutan sampah hingga menumpuk dan kotor.

"Sampah di laut selama ini tidak ada yang angkat baik warga ataupun pihak pemerintah, jadi sampah di laut selalu menumpuk, dan masyarakat banyak mengeluh karena sampah di laut banyak dan kotor." (17 Juli 2019)

$\mathrm{Bu}$ Harnina (48) menjelaskan bahwa petugas pengangkutan sampah memakai atribut lengkap, namun petugas hanya mengankut sampah di darat saja.

Pengangkatan sampah setiap hari oleh petugas di depan rumah warga, mereka dengan peralatan lengkap. Tapi untuk sampah yang ada di laut petugas tidak ambil, mereka hanya mengangkat sampah yang ada di darat saja. (17 Juli 2019)

Dari Warga Kampung Bugis Pak Rusman (62) beliau menyesalkan pengangkutan sampah hanya diprioritaskan pada wilayah darat saja 
sedangkan wilayah pesisir dan laut jarang disentuh oleh petugas pengangkutan sampah. Beliau menyatakan masyarakat sudah merasa sulit mengatasi sampah yang terus datang kepemukiman mereka dan memohon kepada Pak Camat untuk melakukan pengangkutan sampah di laut.

"Untuk pengangkatan sampah di daerah daratan tidak ada masalah, tapi di daerah pantai tidak ada tong sampah, masyarakat pesisir pantai rata-rata membuang sampah di laut. Sekarang sampah di laut sudah terlalu banyak, masyarakatpun sekarang kebingungan mengatasinya. Kalau dilihat sampah di pantai sudah sangat menumput tidak ada yang angkat dari laut. Kami mohon kepada pak camat Belakang Padang agar ada pengangkatan sampah di laut, karena ini meresahkan masyarakat. Karena rumah-rumah di laut dan pesisir mereka membuang sampah di laut tidak ada kesadaran" (17 Juli 2019)

Menurut Bapak Yanto (54) selaku Petugas Pengangkutan Sampah di Kecamatan Belakang Padang, mereka tidak dapat mengangkut sampah di laut karena tidak memiliki boat/kapal. Mereka sudah membersihkan sampah yang ada dipesisit namun sampah tersebut memang tidak kunjug habis karena akan ada lagi setiap pagi.

"Khusus sampah laut, susah disini tidak bersih-bersih, tiap hari diangkat dari laut, tapi paginya ada lagi sampah di laut. Saat ini kita belum ada Boat untuk mengangkat sampah di laut, saat ini kita hanya pake mobil angkat sampah di laut yang di bibir pantai." (11 Juli 2019)

3) Kurangnya Sosialisasi

Menurut Pak Royanto (56) warga Kelurahan Sekanak Raya selama ini belum ada sosialisasi tentang pembuangan sampah di wilayah pesisir.

"Untuk sosialisasi pengangkatan sampah di masyarakat, sebagai RW selama ini belum ada sosialisasi di wilayah pesisir." (17 Juli 2019) 
Ibu Harninan (48) Tahun Warga Kelurahan Tanjung Sari merasakan ditempatnya juga belum perna ada sosialisasi.

"Sosialisasi tidak membuang sampah di laut, atau sembarang tempat tidak dilakukan oleh pemerintah." (17 Juli 2019)

e. Ketepatan layanan

Untuk ketepatan layanan menurut Ibu Windi (45) Warga Kelurahan Sekanak Raya menjelaskan pengankutan sampah di wilayahnya sangat membantu warga untuk tidak membuang sampah jauh ke TPA.

"Dengan adanya pengangkatan sampah sangat membantu warga, tidak perlu jauh-jauh ke tempat pembuangan sampah yang besar." (16 Juli 2019)

Pendapat ini juga diperkuat oleh Ibu Harninan (48) Tahun Warga Kelurahan Tanjung Sari, beliau menginginkan program pengangkutan sampah ini harus terus dilanjutkan karena sangat penting bagi masyarakat karena kalo tidak diangkat akan menyebabkan bau yang tidak sedap.

"Untuk program pengangkatan sampah yang selama ini telah berjalan harus dilanjutkan lagi karena sangat penting. Kalau tidak diangkat sampah akan bau." (17 Juli 2019)

\section{KESIMPULAN}

Pengangkutan sampah di Kecamatan Belakang untuk di dua kelurahan umumnya sudah berjalan baik, namun pengangkutan sampah di laut yang belum jalan dan 4 kelurahan lainnya masih belum tersentu pelayanan.

1. Indikator Masukan Kebijakan

a. Peraturan sudah ada untuk menunjang aktifitas mengangkutan sampah di Kecamatan Belakang Padang yang sekarang dibebankan tanggung jawab pengangkutan sampah kepada Kecamatan; 
b. Organisasi Pelaksana yakni Kecamatan dan Satuan Petugas Pengangkutan Sampah;

c. Sumberdaya, 1) Sumberdaya Manusia sudah cukup dan merata disetiap jabatan; 2) Fasilitas harus diperhatikan karena mobil pick up dan tosa Rusak, selain itu untuk wilayah kepulauan seharusnya satgas dilengkapi dengan boat/kapal untuk mengangkut sampah di laut; dan 3) Anggaran, anggaran sudah dialokasikan dengan baik oleh Kecamatan Belakang Padang.

2. Indikator Keluaran Kebijakan

a. Akses, akses pembuangan sampah masih kurang baik dikarenakan masih kurangnya tempat sampah dan tempat pembuangan sampah sementara. Namun satgas bekerja dengan baik dengan mengangkut sampah dengan tertib. Untuk sampah di laut masih susah dijangkau.

b. Frekuensi, Petugas pengangkut sampah sudah sesuai dengan SOP yakni Senin Sabtu sebanyak 3 kali angkut dalam 1 hari.

c. Cakupan, Cakupan mengangkutan sampah masih di lakukan di 2 keluarahan saja. 4 kelurahan laiinya belum terlayani.

d. Bias, masih belum adanya pengangkutan sampah di laut, pemerintah kurang melakukan sosialisasi, dan masih adanya kelurahan yang belum tersentu pelayanan.

e. Ketepatan Layanan, pelayanan pengangkutan sampah dirasa sangat tepat untuk dilaksanakan dikarena sangat vital perannya untuk masyarakat.

Saran

1. Untuk menambah tempat sampah di lingkungan warga

2. Untuk menambah jumlah Tempat Pembuangan Sementara

3. Untuk memperbaiki Mobil dan Becak Motor

4. Untuk melakukan mengadaan Boat/Kapal pagangkut sampah di laut

5. Untuk melakukan sosialisasi kepada masyarakat

6. Untuk memberikan pelayanan pengangkutan sampah di 4 kelurahan yang belum terlayani. 


\section{REFERENSI}

Sulistya Ekawati. 2016. Mengkritisi Kebijakan Penanganan Kantong Plastik di Indonesia.

Pusat Penelitian dan Pengembangan Sosial, Ekonomi, Kebijakan dan Perubahan Iklim: Volume 10 No 6

Purwanto, Erwan Agus dan Sulistyastuti, Dyah Ratih. 2012. Implemetasi Kebijakan Publik, Konsep, dan Aplikasinya di Indonesia. Yogyakarta: Gava Media

Darmawan Triwibowo dan Nur Iman Subono (ed), 2009, Meretas Arah Kebijakan Sosial Baru di Indonesia; Lebih dari Sekedar Pengurangan Kemiskinan, Jakarta; LP3ES

Cole and Parston. 2006. Unlocking Public Values. New Jersey and etc: John Wiley and Sons

Nawawi, Hadari. 1992. Metode Penelitian Bidang Sosial. Yogyakarta: Press

Sugiyono. 2009. Metode Penelitian Kuantitatif, Kualitatif, dan R\&D. Bandung: Alfabeta

Solihin, Muhammad dan Parlindungan, Ronald. 2018. Implementasi Program Pengangkutan Sampah di Kota Batam Tahun 2017. Trias Politika. Volume 2 No 2 